\title{
EFEK EKSTRAK ETANOL DAGING BUAH MAHKOTA DEWA (Phaleria macrocarpa (Scheff.) Boerl.) TERHADAP PENURUNAN KADAR ASAM URAT PADA MENCIT PUTIH JANTAN YANG DIINDUKSI POTASSIUM OXONATE
}

\author{
THE EFFECT OF ETANOL EXTRACT OF MAHKOTA DEWA PULP (Phaleria macrocarpa \\ (Scheff.) Boerl.) TOWARDS THE REDUCTION OF URIC ACID IN WHITE MALE MICE \\ INDUCTED BY POTASSIUM OXONATE
}

\author{
EM. Sutrisna*, Arifah Sri Wahyuni, Ulul Azmi \\ Fakultas Farmasi Universitas Muhammadiyah Surakarta \\ em_sutrisna@yahoo.com
}

\begin{abstract}
ABSTRAK
Mahkota dewa (Phaleria macrocarpa (Sceff.) Boerl.) merupakan tanaman obat yang digunakan secara empiris sebagai obat berbagai penyakit salah satunya asam urat. Asam urat adalah produk akhir metabolisme purin pada manusia. Penelitian ini bertujuan untuk mengetahui efek ekstrak etanol daging buah mahkota dewa dalam menurunkan kadar asam urat mencit putih jantan yang diinduksi potassium oxonate $250 \mathrm{mg} / \mathrm{kgBB}$. Dua puluh lima ekor mencit jantan diberi jus hati ayam konsentrasi 10\% 3 kali sehari selama 2 hari, lalu dibagi menjadi 5 kelompok. Kelompok I kontrol negatif (CMC Na 0,5\% p.o 0,5ml/20gBB). Kelompok II kontrol positif (allopurinol p.o 10mg/kgBB). Kelompok III, IV dan V diberi sediaan ekstrak etanol daging buah mahkota dewa dosis berturut-turut 1,25; 2,5 dan 5g/kgBB. Kelompok I-V dibuat hiperurisemia dengan induksi potassium oxonate $250 \mathrm{mg} / \mathrm{kgBB}$ secara intraperitoneal 1 jam setelah pemberian sediaan uji. Darah diambil dari vena opthalmicus 2 jam setelah pemberian potassium oxonate, serum ditambah reagen uric acid ${ }^{*}$ FS TBHBA (2,4,6,tribromo 3-hydroxy benzoid acid) dan dibaca kadar asam uratnya pada panjang gelombang $546 \mathrm{~nm}$. Data persentase penurunan kadar asam urat diuji dengan ANAVA satu jalan (taraf kepercayaan 95\%) dilanjutkan uji Bonferroni. Hasil penelitian menunjukkan sediaan ekstrak etanol daging buah mahkota dewa dosis 1,25; 2,5 dan 5g/kgBB mampu menurunkan kadar asam urat pada serum darah mencit putih jantan yang diinduksi potassium oxonate. Ekstrak etanol daging buah mahkota dewa dosis 1,25; 2,5 dan 5g/kgBB mempunyai potensi yang sama dengan allopurinol dosis $10 \mathrm{mg} / \mathrm{kgBB}$ dalam menurunkan kadar asam urat tetapi kemampuan penurunannya lebih allopurinol.
\end{abstract}

Kata kunci : Phaleria macrocarpa (Sceff.) Boerl., potassium oxonate, asam urat

\section{ABSTRACT}

Mahkota dewa (Paleria macrocarpa (Scheff.) Boerl) is a medical plant which empirically is used to heal such disease as uric acid. Uric acid is the final product of purin metabolism in human being. This research is purposed to know how the effect of etanol extract of mahkota dewa pulp in reducing the level of uric acid in white male mice with inducted by potassium oxonate 250 $\mathrm{mg} / \mathrm{kgBW}$. Twenty five of white male mice were given giblets juices with $10 \%$ concentration in three times a day during two days, and then devided into 5 groups. The group 1 is negative control (CMC $\mathrm{Na} 0,5 \%$ p.o 0,5 ml/20gBW). The group 2 is positive contro (Allopurinol p.o $10 \mathrm{mg} / \mathrm{kgBW}$ ). The group 3, 4 and 5 were given by etanol extract preparation of mahkota dewa pulp in sequence 1,25; 2,5 and $5 \mathrm{~g} / \mathrm{kgBW}$ dosage. The group 1-5 were made hyperuricemia with induction of potassium oxonate $250 \mathrm{mg} / \mathrm{kgBW}$ intraperitoneally during 1 hour after giving the test preparation. Blood is taken from vena opthalmicus at 2 hour after giving potassium oxonate, the serum added with uric acid reagent ${ }^{*} F S \operatorname{TBHBA}(2,4,6$, tribromo 3-hydroxy benzoic acid) and read the level of uric acid at $\lambda 546 \mathrm{~nm}$. The percentage data of the uric acid level reducing are tested by one way ANAVA (level of validity) and continued by Bonferroni test. The result of this research represents the etanol extract preparation of mahkota dewa pulp 1,25;2,5 and $5 \mathrm{~g} / \mathrm{kgBW}$ dosage could reduce the level of uric acid in white male of mice serum inducted by potassium oxonate. Etanol extract of mahkota dewa pulp 1,25; 2,5 and $5 \mathrm{~g} / \mathrm{kgBW}$ dosage has the potential which is same with allopurinol 10 $\mathrm{mg} / \mathrm{kgBW}$ dosage in reducing the level of uric acid but its ability in reducing uric acid is not as big as allopurinol.

Keywords : Phaleria macrocarpa (Scheff.) Boerl.), potassium oxonate, uric acid.

62 PHARMACON, Vol. 11, No. 2, Desember 2010, Sutrisna, EM.et al. (62-69) 


\section{PENDAHULUAN}

Asam urat adalah penyakit gangguan metabolik yang disebabkan penumpukan asam urat (uric acid) dalam jaringan tubuh (Anonim, 2009). Asam urat merupakan produk akhir metabolisme purin yang dapat mengendap dalam jaringan dan peradangan yang dikenal dengan nama gout atau encok. Gout atau pirai merupakan penyakit metabolik yang terjadi akibat tingginya kadar asam urat dalam darah (Simon et al., 2001). Asam urat biasanya menyerang pria berumur lebih dari 40 tahun dan perempuan pascamenopouse. Salah satu pemicu utama timbulnya penyakit asam urat adalah perubahan gaya hidup seseorang yang disertai dengan pola makan yang salah (Sudewo, 2004). Akibat lebih lanjut dari meningkatnya asam urat adalah pembentukan tofi (kapur) di sekitar sendi, kelainan ginjal serta pembentukan batu urat (Winarto dan Karyasari, 2003).

Penelitian dan pengembangan tanaman obat telah berkembang pesat, terutama pada segi farmakologi maupun fitokimianya. Penelitian ini digunakan untuk mencari tanaman yang berpotensi sebagai tanaman obat. Salah satu tanaman yang dikembangkan adalah mahkota dewa. Berdasarkan pengalaman empiris, buah mahkota dewa sangat manjur untuk menyembuhkan asam urat. Selain itu, tanaman tersebut juga digunakan untuk mengobati berbagai penyakit yakni lever, kanker dan tekanan darah tinggi (Harmanto, 2001). Daun dan kulit buah mahkota dewa segar atau yang telah dikeringkan juga dapat digunakan sebagai antitumor, disentri dan sakit kulit (Gotama, 1999).

Beberapa hasil penelitian yang telah dilakukan menunjukkan bahwa tanaman mahkota dewa mempunyai potensi sebagai antiinflamasi (Siswanto, 2005), antihistamin (Siswono, 2001) dan memiliki efek penghambatan pada sel kanker leukemia THP1 (Kurnia, dkk., 2005). Daging buah mahkota dewa juga mempunyai efek hipoglikemik (Primsa, 2002). Hasil uji keamanan menunjukkan perasan daging buah segar mahkota dewa tidak mempengaruhi fungsi ginjal pada tikus putih jantan dan betina pada pemakaian jangka panjang (Hendra, 2005). Perasan daging buah mahkota dewa telah terbukti efektif menurunkan kadar asam urat pada ayam jantan jenis Lohman Brown dengan dosis 13,16g/kgBB (Hasturani, 2003).

Berdasarkan penelitian Arini (2003), diketahui bahwa daging buah mahkota dewa mengandung flavonoid. Ekstrak etanol $70 \%$ daging buah mahkota dewa mempunyai kadar relatif flavonoid yang paling besar $(45,73$ $\mu \mathrm{g} / \mathrm{mg}$ ). Keefektifan mahkota dewa untuk mengobati asam urat diduga didasarkan pada kandungan flavonoidnya. Kemampuan senyawa tersebut dalam menurunkan asam urat adalah dengan mekanisme hambatan terhadap aktivitas xantin oksidase pada basa purin sehingga akan menurunkan produksi asam urat. Dari harga $I_{50}$ flavonoid menyatakan bahwa $50 \%$ penghambatan xantin oksidase sama dengan $50 \%$ penurunan produksi asam urat. Jenis flavonoid yang berperan dalam mekanisme penghambatan enzim xantin oxidase adalah flavon dan flavonol (Cos et.al., 1998). Flavonoid dalam tanaman mahkota dewa dapat berbentuk aglikon maupun glikosida. Kepolaran senyawa flavonoid adalah dari non polar sampai dengan polar sehingga dapat disari dalam penyari yang non polar sampai dengan polar (Markham, 1988).

Allopurinol digunakan untuk mengobati asam urat sejak bertahun-tahun yang lalu, akan tetapi allopurinol dapat menimbulkan efek samping yaitu kerusakan gastrointestinal, reaksi alergi dan toksisitas pada hati (Mo et.al., 2007). Selama ini penggunaan mahkota dewa sebagai obat asam urat hanya berdasarkan pada pembuktian empiris dan pengalaman pengguna. Berdasarkan penggunaan secara empiris dan dari hasil penelitian yang telah dilakukan sebelumnya, maka ekstrak etanol daging buah mahkota dewa berpotensi untuk dikembangkan menjadi fitofarmaka. Untuk itu perlu dilakukan penelitian tentang ekstrak etanol daging buah mahkota dewa untuk membuktikan keefektifannya sebagai penurun kadar asam urat. Hasil penelitian ini diharapkan dapat dijadikan sebagai bukti ilmiah bahwa tanaman mahkota dewa dapat dijadikan sebagai obat untuk menurunkan kadar asam urat.

\section{METODE PENELITIAN}

Alat : Oven, blender, ayakan, panci stainless steel, timbangan analitik (Presica A-SCS), alatalat gelas (Pyrex), spuit injeksi, jarum oral ukuran 15 gauge (Terumo), timbangan mencit, pipa kapiler, ependorf, sentrifuge, alat vortex, spektrofotometer (Star Dust FC* 15), kuvet dan mikropipet berbagai ukuran.

Bahan : Daging buah mahkota dewa (Phaleria macrocarpa (Scheff.) Boerl), mencit putih jantan dengan berat badan 20-30 gram dan berumur 2-3 bulan, potassium oxonate p.a. (Aldrich Chemical Company), etanol $70 \%$ teknis, CMC $\mathrm{Na} 0,5 \%$, allopurinol p.a. (Sigma) dan aquadest dan reagen Uric Acid FS TBHBA (2,4,6, Tribromo 3-hydroxy benzoid Acid) dari DiaSys. 


\section{JALANNYA PENELITIAN \\ Pengambilan Bahan dan Pembuatan Serbuk Simplisia}

Buah mahkota dewa diambil dari daerah Tawangmangu, Karanganyar, Jawa Tengah. Buah dipanen setelah masak, berwarna merah tua, baunya manis, daging buahnya berwarna putih dan berasa sepat.

Buah mahkota yang sudah dipisahkan dengan bijinya, dicuci dengan air yang mengalir untuk menghilangkan kotoran. Kemudian dikeringkan dengan oven agar pengeringannya merata dalam waktu cepat dan tidak dipengaruhi oleh cuaca. Selanjutnya dibuat serbuk dengan cara diblender hingga halus. Semakin halus serbuk maka luas permukaan akan semakin besar, namun jika serbuk terlalu halus maka serbuk akan lolos dalam penyaringannya.

\section{Pembuatan Ekstrak Etanol Mahkota Dewa}

Pembuatan ekstrak etanol mahkota dewa menggunakan metode maserasi. Serbuk mahkota dewa sebanyak 300 gram dimasukkan ke dalam sebuah bejana tertutup lalu direndam dengan etanol $70 \%$ sebanyak $1250 \mathrm{ml}$ hingga semua bagian serbuk terendam selama 5 hari dengan beberapa kali penggojokan. Setelah 5 hari diserkai dan diperas. Kemudian sari diendapkan selama 1 malam lalu disaring dan filtratnya disimpan (filtrat 1). Selanjutnya ampas ditambahkan $850 \mathrm{ml}$ etanol $70 \%$ hingga semua bagian ampas terendam lalu ditutup, dibiarkan selama 2 hari terlindung dari cahaya sambil diaduk tiga kali sehari. Kemudian diserkai dan diperas. Sari etanol dipindahkan ke bejana tertutup, dibiarkan di tempat sejuk yang terlindung dari cahaya selama 2 hari untuk diendapkan lalu disaring (filtrat 2). Filtrat 1 dan 2 digabung dan diuapkan dengan evaporator. Kemudian dipekatkan dengan menggunakan cawan porselin di atas penangas air sampai pelarut menguap semua sehingga didapat ekstrak kental.

\section{Pemilihan dan Pengadaptasian Hewan Uji}

Hewan uji yang digunakan untuk penelitian adalah mencit putih jantan galur Swiss dengan berat badan antara 20-30 gram yang berumur 2-3 bulan. Pengadaptasian mencit dilakukan di Laboratorium Farmakologi Fakultas Farmasi UMS selama 1 minggu dan diberi makanan standar dan minuman aquadest ad libitum.

\section{Penentuan Dosis Ekstrak Etanol Daging Buah Mahkota Dewa}

Volume maksimal yang dapat diberikan pada mencit dengan berat badan antara 20-30 gram adalah $1 \mathrm{ml}$, tetapi untuk volume pemberiannya adalah $1 / 2$ dari volume maksimal.

Dosis ekstrak etanol daging buah mahkota dewa diperoleh dengan melakukan orientasi dosis terlebih dahulu. Orientasi dosis dilakukan dengan menggunakan 5 ekor hewan uji yang diberi sediaan ekstrak etanol dosis tengah yakni $2,5 \mathrm{~g} / \mathrm{kgBB}$. Setelah itu, dosis tersebut akan diterapkan seterusnya pada uji perlakuan.

\section{Penentuan Peringkat Dosis Allopurinol dan Potassium Oxonate}

Dosis alopurinol yang digunakan adalah $10 \mathrm{mg} / \mathrm{kgBB}$ atau $0,2 \mathrm{mg} / 20 \mathrm{gBB}$, sedangkan dosis potassium oxonate yang digunakan secara intraperitoneal pada mencit adalah $250 \mathrm{mg} / \mathrm{kgBB}$ atau $5 \mathrm{mg} / 20 \mathrm{gBB}$. Dosis ini mengacu pada penelitian sebelumnya (Zhao et al., 2005).

\section{Pembuatan Hiperurisemia}

Kadar asam urat tinggi (hiperurisemia) dibuat dengan cara penginduksian potassium oxonate secara intraperitoneal dengan dosis $250 \mathrm{mg} / \mathrm{kgBB}$ atau $5 \mathrm{mg} / 20 \mathrm{gBB}$ pada mencit 1 jam setelah pemberian sediaan uji (Mo et al, 2007). Akan tetapi sebelum hewan uji digunakan untuk penelitian, diberi makanan tambahan berupa jus hati ayam dengan konsentrasi 10\% 3 kali sehari selama 2 hari.

\section{Uji Pendahuluan dan Uji Perlakuan terhadap Hewan Uji}

Sebelum digunakan untuk penelitian, hewan uji diadaptasikan selama 1 minggu dan diberi makanan tambahan berupa jus hati ayam dengan konsentrasi 10\% 3 kali sehari selama 2 hari. Pengujian yang dilakukan terlebih dahulu adalah uji pendahuluan untuk pembuatan model hiperurisemia. Sebanyak 9 ekor mencit putih jantan ditimbang lalu dibagi menjadi 3 kelompok masing-masing 3 ekor, yaitu :

1. Kontrol CMC Na 0,5\% : diberi CMC Na 0,5\% p.o $0,5 \mathrm{ml} / 20 \mathrm{gBB}$, satu jam kemudian diberi CMC Na $0,5 \%$ i.p 0,5ml/20gBB.

2. Kontrol normal (aquades) : diberi aquades p.o $0,5 \mathrm{ml} / 20 \mathrm{gBB}$, satu jam kemudian diberi aquades i.p $0,5 \mathrm{ml} / 20 \mathrm{gBB}$.

3. Kelompok Hiperurisemia : diberi aquades p.o $0,5 \mathrm{ml} / 20 \mathrm{gBB}$, satu jam kemudian diinduksi dengan potassium oxonate i.p $250 \mathrm{mg} / \mathrm{kgBB}$.

Induksi potassium oxonate dilakukan ketika terjadi akumulasi asam urat yaitu antara jam 09.00 dan 10.00 pagi. Pengambilan darah dilakukan pada waktu yang menunjukkan kadar asam urat tertinggi yaitu pada jam ke-2 (Haidari et al., 2008). Pengujian selanjutnya adalah uji perlakuan, menggunakan 25 ekor mencit yang 
telah ditimbang lalu dibagi menjadi 5 kelompok masing-masing 5 ekor, yaitu:

1. Kontrol negatif : diberi CMC Na 0,5\% p.o $0,5 \mathrm{ml} / 20 \mathrm{gBB}$

2. Kontrol positif : diberi allopurinol p.o $10 \mathrm{mg} / \mathrm{kgBB}$ atau $0,2 \mathrm{mg} / 20 \mathrm{gBB}$

3. Ekstrak etanol 1 : diberi ekstrak etanol daging buah mahkota dewa p.o dosis $1,25 \mathrm{~g} / \mathrm{kgBB}$

4. Ekstrak etanol 2 : diberi ekstrak etanol daging buah mahkota dewa p.o dosis $2,5 \mathrm{~g} / \mathrm{kgBB}$

5. Ekstrak etanol 3 : diberi ekstrak etanol daging buah mahkota dewa p.o dosis $5 \mathrm{~g} / \mathrm{kgBB}$

Satu jam setelah perlakuan, diinduksi dengan potassium oxonate secara intraperitoneal 250mg/kgBB. 2 jam kemudian darah diambil melalui vena opthalmicus dari mata mencit menggunakan pipa kapiler lalu darah ditampung $( \pm 0,5 \mathrm{ml})$ dalam tabung ependorf. Darah dialirkan lewat dinding tabung ependorf untuk menghindari terjadinya hemolisis. Darah disentrifugasi dengan kecepatan 5000 rpm selama 5 menit untuk mendapatkan serumnya. Serum yang telah memisah diambil dengan mikropipet dan ditempatkan dalam tabung ependorf baru. Serum dibaca kadar asam uratnya pada panjang gelombang $546 \mathrm{~nm}$.

\section{Penetapan Kadar Asam Urat}

Kadar asam urat ditetapkan berdasarkan reaksi enzymatic menggunakan reagen uric acid FS* TBHBA. Larutan sampel dibuat dengan cara mengambil $20 \mu \mathrm{l}$ serum ditambah $1000 \mu \mathrm{l}$ monoreagen (4 bagian Reagen 1 ditambah 1 bagian Reagen 2). Serum yang telah dicampur homogen dengan pereaksi Uric Acid FS* TBHBA diinkubasi selama 6-8 menit pada suhu $37^{\circ} \mathrm{C}$. Selanjutnya larutan sampel, standart dan blangko dibaca kadarnya dengan menggunakan spektrofotometer StartDust FC* 15 pada panjang gelombang $546 \mathrm{~nm}$.

\section{Analisis Data}

Data yang diperoleh dari penelitian yang berupa kadar asam urat dalam darah dianalisa distribusi normalitasnya menggunakan uji Kolmogorov-Smirnov dan juga homogenitasnya dengan Levene test. Data tersebut terdistribusi normal dan homogen maka analisa dilanjutkan dengan ANAVA satu jalan dilanjutkan dengan uji Bonferroni dengan taraf kepercayaan 95\%.

Untuk melihat potensi ekstrak etanol dalam menurunkan kadar asam urat pada serum darah mencit putih jantan yang dibuat hiperurisemia digunakan persen penurunan kadar asam urat dengan rumus :

Rata-rata kontrol negatif (CMC Na 0,5\%) - kadar setelah perlakuan

Rata-rata kontrol negatif (CMC Na 0,5\%)

\section{HASIL DAN PEMBAHASAN}

\section{Hasil Uji Pendahuluan}

Uji pendahuluan dilakukan untuk membuat model hiperurisemia pada mencit putih jantan dengan cara diinduksi potassium oxonate dosis $250 \mathrm{mg} / \mathrm{kgBB}$ secara intraperitoneal antara pukul 09.00 dan 10.00 (Haidari et al., 2008). Uji dilakukan dengan membandingkan kadar asam urat kontrol CMC $\mathrm{Na} 0,5 \%$ dan kontrol aquadest dengan kelompok hiperurisemia (tabel 1). Dosis potassium oxonate $250 \mathrm{mg} / \mathrm{kgBB}$ yang digunakan pada penelitian ini mengacu pada penelitian sebelumnya (Zhao et al., 2005). Waktu pengambilan darah yang optimal dilakukan pada jam ke-2. Hal ini didukung oleh penelitian yang menyatakan bahwa waktu pengambilan darah yang optimal adalah pada jam ke-2 setelah diinduksi potassium oxonate $250 \mathrm{mg} / \mathrm{kgBB}$ secara intraperitoneal (Haidari et al., 2008).

Tabel 1- Data Perbandingan Kadar Asam Urat Kontrol CMC Na 0,5\% dan Aquadest Dengan Kelompok Hiperurisemia

\begin{tabular}{cccc}
\hline Perlakuan & Hewan uji & $\begin{array}{c}\text { Kadar } \\
\text { Asam } \\
\text { Urat } \\
\text { (mg/dL) }\end{array}$ & $\begin{array}{c}\bar{X} \pm \mathrm{SD} \\
(\mathrm{mg} / \mathrm{dL})\end{array}$ \\
\hline CMC Na & 1 & 2,4 & \\
$0,5 \%$ i.p & 2 & 2,5 & $2,57 \pm 0,21$ \\
Aquadest & 3 & 2,8 & \\
(normal) & 1 & 1,8 & \\
& 2 & 2,6 & $1,80 \pm 0,80$ \\
Potassium & 3 & 1,0 & \\
Oxonate & 1 & 3,4 & \\
250mg/kgB & 3 & 3,6 & $4,13 \pm 1,10$ \\
(hiperurisemia) & 3 & 5,4 &
\end{tabular}

Data hasil uji pendahuluan diuji statistik dengan SPSS 17.0 for windows. Hasil uji menunjukkan bahwa data tersebut terdistribusi normal dan variansinya homogen. Selanjutnya dilakukan uji Post-Hoc test Bonferroni untuk mengetahui kelompok mana yang berbeda secara bermakna.

Hasil uji Post-Hoc test Bonferroni menunjukkan bahwa kelompok I (kontrol CMC $\mathrm{Na} 0,5 \%$ ) tidak berbeda bermakna dengan kelompok II (kontrol aquadest) dengan nilai signifikansi 0,847 (p>0,05). Hal ini berarti pemberian aquadest tidak mempengaruhi peningkatan kadar asam urat dalam serum mencit jantan yang dibuat hiperurisemia. Kelompok I (kontrol CMC Na 0,5\%) menunjukkan perbedaan yang tidak bermakna dengan kelompok III (kelompok hiperurisemia) dengan nilai signifikansi 0,157 ( $p>0,05)$, yang berarti bahwa penggunaan CMC Na 0,5\% sebagai pensuspensi dari potassium oxonate dapat mempengaruhi peningkatan kadar asam urat pada serum darah mencit jantan yang dibuat hiperurisemia, sehingga penggunaan CMC Na 0,5\% sebagai suspending agent harus dikontrol. Pengaruh CMC Na $0,5 \%$ dalam meningkatkan kadar asam urat ditunjukkan oleh perbedaan nilai SD yang besar antara CMC Na $0,5 \%$ dan aquadest. Oleh karena itu, CMC Na 
0,5\% yang juga digunakan sebagai suspending agent sediaan uji pada uji perlakuan dapat digunakan sebagai kontrol negatif untuk mengetahui efek ekstrak etanol mahkota dewa dalam menurunkan kadar asam urat secara tepat. Pada kelompok II (kontrol aquadest) menunjukkan hasil yang berbeda bermakna dengan kelompok III (kelompok hiperurisemia) dengan nilai signifikansi $0,034(p<0,05)$. Hal ini berarti pemberian potassium oxonate dosis 250 $\mathrm{mg} / \mathrm{kgBB}$ mampu meningkatkan kadar asam urat secara nyata dari kondisi normal, sehingga pembuatan model hiperurisemia dapat dikatakan berhasil. Menurut Mo et al., (2007) mencit dikatakan hiperurisemia apabila kadar asam uratnya mencapai lebih dari $3,3 \mathrm{mg} / \mathrm{dL}$.

\section{Hasil Uji Ekstrak Etanol Daging Buah Mahkota Dewa}

Tabel 2- Data Kadar Asam Urat Awal (Baseline) dan Kadar Setelah Perlakuan pada Serum Mencit Jantan

\begin{tabular}{|c|c|c|c|}
\hline Kelompok & $\begin{array}{l}\text { No. } \\
\text { HU }\end{array}$ & $\begin{array}{c}\text { Kadar } \\
\text { awal/baselin } \\
e(\mathrm{mg} / \mathrm{dl})\end{array}$ & $\begin{array}{c}\text { Kadar } \\
\text { setelah } \\
\text { perlakuan } \\
(\mathrm{mg} / \mathrm{dL}) \\
\end{array}$ \\
\hline \multirow{6}{*}{$\begin{array}{c}\text { Kontrol Negatif } \\
\text { (CMC Na } \\
0,5 \%)\end{array}$} & & 1,1 & 2,4 \\
\hline & & 1,0 & 2,5 \\
\hline & & 1,5 & 2,8 \\
\hline & & 1,2 & 2,6 \\
\hline & & 1,3 & 2,5 \\
\hline & & $\begin{array}{l}\bar{X} \pm \mathrm{SD}= \\
1,22 \pm 0,19\end{array}$ & $\begin{array}{l}\bar{X} \pm \mathrm{SD}= \\
2,56 \pm 0,15\end{array}$ \\
\hline \multirow{6}{*}{$\begin{array}{c}\text { Kontrol Positif } \\
\text { (Allopurinol } \\
\text { 10mg/kgBB) }\end{array}$} & & 2,6 & 1,3 \\
\hline & & 1,3 & 0,5 \\
\hline & & 3,1 & 0,8 \\
\hline & & 2,5 & 1,3 \\
\hline & & 1,8 & 0,8 \\
\hline & & $\begin{array}{l}\bar{X} \pm \mathrm{SD}= \\
2,26 \pm 0,71\end{array}$ & $\begin{array}{l}\bar{X} \pm \mathrm{SD}= \\
0,94 \pm 0,35\end{array}$ \\
\hline \multirow{6}{*}{$\begin{array}{c}\text { Ekstrak etanol } \\
\text { daging buah } \\
\text { mahkota dewa } \\
\text { dosis } \\
1,25 \mathrm{~g} / \mathrm{kgBB}\end{array}$} & & 2,1 & 1,2 \\
\hline & & 2,5 & 1,4 \\
\hline & & 2,6 & 1,8 \\
\hline & & 1,9 & 1,4 \\
\hline & & 1,8 & 1,0 \\
\hline & & $\begin{array}{r}\bar{X} \pm \text { SD } \\
2,18 \pm 0,36\end{array}$ & $\begin{array}{l}\bar{X} \pm S D= \\
1,36 \pm 0,30\end{array}$ \\
\hline \multirow{6}{*}{$\begin{array}{c}\text { Ekstrak etanol } \\
\text { daging buah } \\
\text { mahkota dewa } \\
\text { dosis } \\
2,5 \mathrm{~g} / \mathrm{kgBB}\end{array}$} & & 1,7 & 1,0 \\
\hline & & 2,1 & 1,2 \\
\hline & & 2,6 & 1,4 \\
\hline & & 2,8 & 1,9 \\
\hline & & 2,2 & 1,7 \\
\hline & & $\begin{array}{l}\bar{X} \pm \mathrm{SD}= \\
2,28 \pm 0,43\end{array}$ & $\begin{array}{l}\bar{X} \pm \mathrm{SD}= \\
1,44 \pm 0,36\end{array}$ \\
\hline \multirow{6}{*}{$\begin{array}{l}\text { Ekstrak etanol } \\
\text { daging buah } \\
\text { mahkota dewa } \\
\text { dosis } 5 \mathrm{~g} / \mathrm{kgBB}\end{array}$} & & 2,6 & 1,2 \\
\hline & & 2,1 & 1,0 \\
\hline & & 2,7 & 1,0 \\
\hline & & 2,3 & 1,0 \\
\hline & & 1,8 & 0,8 \\
\hline & & $\begin{array}{l}\bar{X} \pm \mathrm{SD}= \\
2,30 \pm 0,37\end{array}$ & $\begin{array}{l}\bar{X} \pm \mathrm{SD}= \\
1,00 \pm 0,14\end{array}$ \\
\hline
\end{tabular}

Kenaikan kadar asam urat (hiperurisemia) terjadi pada kadar lebih dari 3,3 $\mathrm{mg} / \mathrm{dL}$ (Mo et al., 2007). Kadar asam urat awal/baseline pada hewan uji masih dalam batas normal (Tabel 2). Data baseline tersebut digunakan untuk mengontrol kadar awal asam urat pada hewan uji.

Data kadar setelah perlakuan pada tabel 2 kemudian diuji statistik dengan SPSS 17.0 for windows. Dari hasil pengolahan data menunjukkan bahwa data kadar setelah perlakuan pada tabel 2 mempunyai variansi yang homogen dan terdistribusi normal ( $>>0,05)$. Untuk mengetahui perbedaan antara 5 kelompok tersebut, maka dilakukan uji statistik analisa varian satu jalan. Hasil analisa varian diperoleh nilai signifikansi sebesar 0,000 $(\mathrm{p}<0,05)$. Dan selanjutnya dilakukan uji PostHoc test Bonferroni untuk mengetahui kelompok mana yang memiliki perbedaan secara bermakna (Gambar 1).

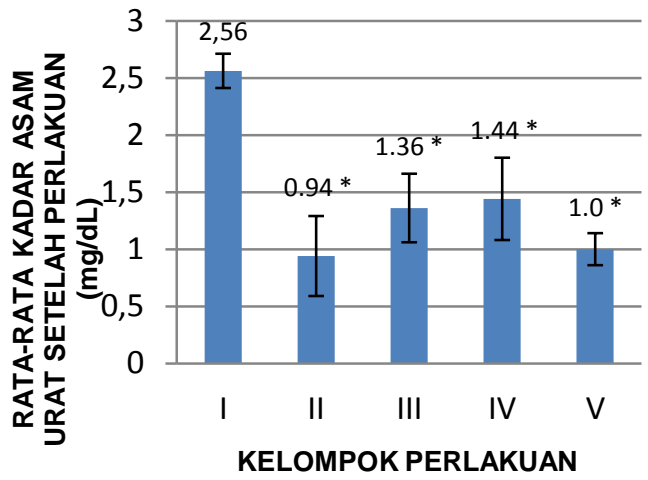

Gambar 1- Histogram Antara Kelompok Perlakuan dengan Kontrol Negatif (CMC Na 0,5\%)

Keterangan :

* : Berbeda bermakna dengan kontrol negatif CMC Na 0,5\% $(\mathrm{p}<0,05)$

Kelompok I : Kontrol Negatif (CMC Na 0,5\%)

Kelompok II : Kontrol Positif (Allpurinol $10 \mathrm{mg} / \mathrm{kgBB}$ )

Kelompok III : Ekstrak etanol daging buah mahkota dewa dosis $1,25 \mathrm{~g} / \mathrm{kgBB}$

Kelompok IV : Ekstrak etanol daging buah mahkota dewa dosis $2,5 \mathrm{~g} / \mathrm{kgBB}$

Kelompok $\mathrm{V}$ : Ekstrak etanol daging buah mahkota dewa dosis $5 \mathrm{~g} / \mathrm{kgBB}$

Dari hasil uji Post-hoc test Bonferroni menunjukkan bahwa kelompok I (kontrol negatif CMC Na o,5\%) berbeda bermakna dengan kelompok II (kontrol positif Allopurinol) dan kelompok III, IV dan V (variasi dosis ekstrak etanol daging buah mahkota dewa) dengan nilai signifikansi $p<0,05$. Hal ini berarti bahwa allopurinol dan variasi dosis ekstrak etanol daging buah mahkota dewa yakni dosis 1,25; 2,5 dan $5 \mathrm{~g} / \mathrm{kgBB}$ dapat menimbulkan efek penurunan kadar asam urat pada mencit jantan yang dibuat hiperurisemia. Untuk mengetahui besarnya potensi ekstrak etanol daging buah mahkota dewa, dapat digunakan persentase penurunan kadar asam urat (Gambar 2). 


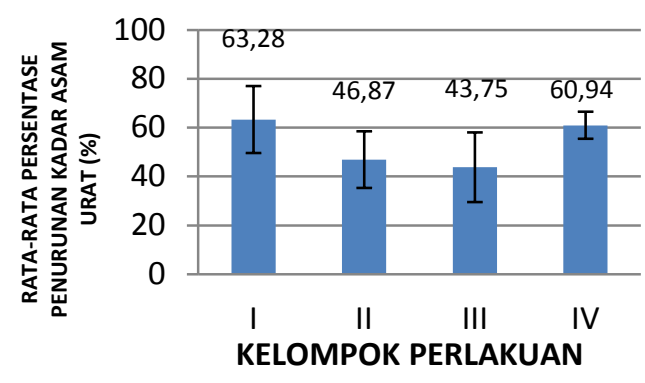

Gambar 2- Histogram Antara Persentase Penurunan dengan Kelompok Perlakuan

Keterangan :

Kelompok I : Kontrol Positif (Allopurinol $10 \mathrm{mg} / \mathrm{kgBB}$ )

Kelompok II : Ekstrak etanol daging buah mahkota dewa dosis $1,25 \mathrm{~g} / \mathrm{kgBB}$

Kelompok III : Ekstrak etanol daging buah mahkota dewa dosis 2,5 g/kgBB

Kelompok IV : Ekstrak etanol daging buah mahkota dewa dosis $5 \mathrm{~g} / \mathrm{kgBB}$

Data persentase penurunan kadar asam urat kemudian dilakukan uji statistik dengan SPSS 17.0 for windows. Hasil uji statistik menunjukkan data persentase penurunan kadar adalah terdistribusi normal dan variansinya homogen. Untuk mengetahui adanya perbedaan terhadap besarnya kadar asam urat yang ditimbulkan maka dilakukan uji statistik analisa ANAVA satu jalan (Lampiran 12). Lalu dilakukan uji post-hoc test Bonferroni untuk mengetahui signifikansi antar perlakuan (Lampiran 13). Hasil uji tersaji di Tabel 3.

Tabel 3- Post-hoc Test Persentase Penurunan Kadar Asam Urat Antara Kelompok Perlakuan

\begin{tabular}{|c|c|c|c|c|}
\hline Kelompok & I & II & III & IV \\
\hline I & & 00,256 & 00,111 & 10,000 \\
\hline II & & & 10,000 & 00,465 \\
\hline III & & & & 00,209 \\
\hline IV & & & & \\
\hline
\end{tabular}

Keterangan :

Kelompok I : Kontrol Positif Allpurinol $10 \mathrm{mg} / \mathrm{kgBB}$

Kelompok II : Ekstrak etanol daging buah mahkota dewa dosis 1,25 g/kgBB

Kelompok III : Ekstrak etanol daging buah mahkota dewa dosis $2,5 \mathrm{~g} / \mathrm{kgBB}$

Kelompok IV : Ekstrak etanol daging buah mahkota dewa dosis $5 \mathrm{~g} / \mathrm{kgBB}$

Hasil uji Post hoc test pada tabel 3 menunjukkan bahwa kelompok I (kontrol positif) tidak berbeda bermakna dengan kelompok II, III dan IV (variasi dosis ekstrak etanol daging buah mahkota dewa) dengan nilai $p>0,05$. Hal ini berarti ekstrak etanol daging buah mahkota dewa dosis 1,$25 ; 2,5$ dan $5 \mathrm{~g} / \mathrm{kgBB}$ berpotensi menurunkan kadar asam urat pada mencit jantan yang dibuat hiperurisemia.

Kelompok II (ekstrak etanol daging buah mahkota dewa dosis 1,25 g/kgBB) menunjukkan perbedaan yang tidak bermakna terhadap kelompok III dan IV (ekstrak etanol daging buah mahkota dewa dosis 2,5 dan 5
g/kgBB) dengan nilai $p>0,05$. Begitu juga antara kelompok III tidak berbeda bermakna terhadap kelompok IV. Hal ini menunjukkan bahwa kelompok II, III dan IV mampu menurunkan kadar asam urat pada mencit jantan yang dibuat hiperurisemia. Ekstrak etanol daging buah mahkota dewa mempunyai potensi yang sama dengan allopurinol dalam menurunkan kadar asam urat, tetapi kemampuannya tidak sebesar kemampuan allopurinol.

Berdasarkan hasil penelitian, sediaan ekstrak etanol daging buah mahkota dewa dosis 1,$25 ; 2,5$ dan $5 \mathrm{~g} / \mathrm{kgBB}$ mampu menurunkan kadar asam urat berturut-turut sebesar 46,87; 43,75 dan 60,94\% dari kondisi hiperurisemia. Salah satu senyawa yang berperan dalam menurunkan kadar asam urat adalah flavonoid (Cos et.al., 1998). Daging buah mahkota dewa diketahui mengandung flavonoid. Ekstrak etanol daging buah mahkota dewa mempunyai kadar flavonoid yang paling besar (45,734 $\mu \mathrm{g} / \mathrm{mg}$ ) (Arini dkk., 2003). Flavonoid dalam tanaman mahkota dewa dapat berbentuk aglikon maupun glikosida. Kepolaran senyawa flavonoid adalah dari non polar sampai dengan polar sehingga dapat disari dalam penyari yang non polar sampai dengan polar (Markham, 1988).

Pernyataan Markham (1988) dikuatkan oleh penelitian Setiani (2010) bahwa infusa daging buah mahkota dewa dosis $2,5 \mathrm{~g} / \mathrm{kgBB}$ efektif menurunkan kadar asam urat darah mencit putih jantan yang dibuat hiperurisemia dengan potassium oxonate dosis $250 \mathrm{mg} / \mathrm{kgBB}$ sekitar $73,77 \%$. Sediaan infusa daging buah mahkota dewa membutuhkan dosis yang lebih kecil daripada sediaan ekstrak etanol dalam menurunkan kadar asam urat. Hal ini dikarenakan senyawa aktif flavonoid yang terikat pada pelarut adalah glikosida yang bersifat polar sehingga lebih larut dalam pelarut polar yaitu air. Keefektifan mahkota dewa pada pelarut non polar dinyatakan oleh Habsari (2010) bahwa ekstrak heksan daging buah mahkota dewa dosis 2,5 g/kgBB mampu menurunkan kadar asam urat mencit jantan yang dibuat hiperurisemia sebesar $71,88 \%$. Hal ini dimungkinkan senyawa aktif flavonoid yang tersari pada pelarut non polar seperti $n$-heksan adalah flavonoid dalam bentuk aglikon. Keefektifan mahkota dewa juga dibuktikan dalam penelitian Pramita (2010) yang menyebutkan bahwa perasan daging buah mahkota dewa dosis $15 \mathrm{~g} / \mathrm{kgBB}$ efektif dalam menurunkan kadar asam urat sebesar $60,16 \%$. Penelitian pada sediaan infusa, ekstrak etanol dan ekstrak heksan daging buah mahkota dewa menunjukkan bahwa flavonoid yang terkandung dalam daging buah mahkota dewa dapat tersari pada pelarut polar dan non polar. 
Hasil penelitian pada sediaan perasan, infusa, ekstrak etanol dan ekstrak heksan daging buah mahkota dewa mempunyai persentase penurunan kadar asam urat yang besar. Hal ini mungkin terjadi karena adanya senyawa lain selain flavonoid yang tersari oleh pelarut pada masing-masing sediaan yang dapat bertanggung jawab dalam menurunkan kadar asam urat.

Mekanisme penurunan kadar asam urat pada penelitian ini didasarkan pada senyawa flavonoid yang terkandung dalam daging buah mahkota dewa. Flavonoid mampu menurunkan kadar asam urat dengan mekanisme hambatan pada aktivitas enzim xantin oksidase sehingga akan menurunkan produksi asam urat. Dari harga $\mathrm{IC}_{50}$ flavonoid menyatakan bahwa $50 \%$ penghambatan xantin oksidase sama dengan $50 \%$ penurunan produksi asam urat. Jenis flavonoid yang berperan dalam mekanisme penghambatan enzim xantin oxidase adalah flavon dan flavonol (Cos et.al, 1998). Adanya senyawa lain selain flavonoid yang terkandung dalam mahkota dewa kemungkinan juga dapat berperan dalam menurunkan kadar asam urat. Oleh karena itu perlu dilakukan penelitian lebih lanjut untuk mengetahui senyawa tersebut.

\section{KESIMPULAN}

Berdasarkan hasil penelitian, ekstrak etanol $70 \%$ daging buah mahkota dewa
(Phaleria macrocarpa (Scheff.) Boerl) dengan dosis 1,$25 ; 2,5$ dan $5 \mathrm{~g} / \mathrm{kgBB}$ mempunyai efek menurunkan kadar asam urat pada mencit putih jantan galur Swiss yang dibuat hiperurisemia dengan induksi potassium oxonate $250 \mathrm{mg} / \mathrm{kgBB}$ sekitar 62,$84 ; 60,66$ dan $72,68 \%$. Ekstrak etanol $70 \%$ daging buah mahkota dewa juga mempunyai potensi yang sama dengan allopurinol dalam menurunkan kadar asam urat, akan tetapi kemampuan menurunkannya tidak sebesar kemampuan allopurinol dosis 10 $\mathrm{mg} / \mathrm{kgBB}$.

\section{SARAN}

1. Perlu dilakukan uji toksisitas untuk mengetahui efek samping yang mungkin terjadi pada penggunaan sediaan dalam jangka pendek dan jangka panjang.

2. Perlu dilakukan penelitian lebih lanjut dengan menggunakan kontrol positif yang berbeda, misal dengan obat asam urat lain.

3. Perlu dilakukan penelitian lebih lanjut untuk pemberian jus hati ayam dalam jangka waktu yang lama dan bagaimana efeknya terhadap kadar asam urat darah.

4. Perlu dilakukan penelitian lebih lanjut untuk mengetahui senyawa lain selain flavonoid yang terkandung dalam mahkota dewa yang dapat berperan dalam menurunkan kadar asam urat.

\section{DAFTAR PUSTAKA}

Anonim, 2009, Asam Urat (online), (http://www.freelist.org/pos/pistons92/asam urat) diakses 10 September 2009)

Arini, S., Dani Nurmawan, Fin Alfiani dan Triana Hertiani, 2003, Daya Antioksidan dan Kadar Flavonoid Hasil Ekstraksi Etanol-Air Daging Buah Mahkota Dewa (Phaleria macrocarpa (Scheff.) Boerl), Jurnal, Fakultas Farmasi, Universitas Gadjah Mada, Jogjakarta.

Cos, P., Ying, L., Calomme, M., Hu, J.P., Cimanga, K., Poel V.B., Pieters, L., Vlietinck, A.J and Berghe, D.V, 1998, Structure-Activity Relationship and Clacification of Flavonoids as Inhibitors of Xanthine Oxidase and Superoxide Scavengers, Journal of Natural Products, 71-76, Vol. 61

Gotama, I.B., 1999, Inventaris Tanaman Obat (V), Depkes Badan Penelitian \& Pengembangan Kesehatan : Jakarta.

Habsari, N. R. E., 2010, Efek Ekstrak Heksan Daging Buah Mahkota Dewa (Phaleria macrocrpa (Scheff.) Boerl) terhadap Penurunan Kadar Asam Urat Mencit Putih Jantan yang Diinduksi Potassium Oxonate, Skripsi, Fakultas Farmasi Universitas Muhammadiyah Surakarta, Surakarta.

Haidari, Fatemeh., Rashidi, M.R., Keshavarz, Seid., Mahboob, S.A., Eshraghian, M.R and Shahi, M.M., 2008, Effect of Onion on Serum Uric Acid Levels and Hepatic Xanthine Dehydrogenase/Xanthine Oxidase Activities in Hyperuricemic Rats, Journal of Biological Sciences, Tehran University of Medical Sciences, Iran.

Harmanto, N., 2001. Mahkota Dewa Obat Pusaka Para Dewa, Agromedia Pustaka, Jakarta.

Hasturani, E., 2003, Efek Air Perasan Daging Buah Mahkota Dewa (Phaleria macrocarpa (Scheff.) Boerl) terhadap Penurunan Kadar Asam Urat pada Ayam Jantan Jenis Lohman Brown, Skripsi, Fakultas Farmasi, Universitas Sanata Dharma, Yogyakarta. 
Hendra, P., 2005, Toksisitas Subkronis Perasan Daging Buah Segar Mahkota Dewa (Phaleria macrocarpa (Scheff.) Boerl) terhadap Fungsi Ginjal Tikus Jantan dan Betina, Jurnal Penelitian, Fakultas Farmasi, Universitas Sanata Dharma, Jogjakarta.

Kurnia, A., Pertamawati, Rifatul dan Hendig, 2005, Efek Penghambat Pertumbuhan Cell-Line THP1 Secara In vitro dari Ekstrak Etanol Buah Mahkota Dewa (Phaleria macrocarpa Scheff.), Jurnal Artocarpus, Vol.5 No. 2 September 2005, 89-94.

Markham, K.R., 1988, Cara Identifikasi Flavonoid, diterjemahkan oleh Padmawinata K., Penerbit ITB, Bandung.

Mo, Shi-Fu., Zhou, Feng., Lv, Yao-Zhong., Hu, Qing-Hua., Zhang, Dong-Mei., and Kong, LingDong., 2007, Hypouricemic Action of Selected Flavonoids in Mice : Structure-Activity Relationship, Nanjing University, China.

Pramita, D., 2010, Efek Perasan Daging Buah Mahkota Dewa (Phaleria macrocrpa (Scheff.) Boerl) terhadap Penurunan Kadar Asam Urat Mencit Putih Jantan yang Diinduksi Potassium Oxonate, Skripsi, Fakultas Farmasi Universitas Muhammadiyah Surakarta, Surakarta.

Primsa, E., 2002, Efek Hipoglikemik Infusa Simplisia Daging Buah Mahkota Dewa (Phaleria macrocarpa (Scheff.) Boerl) pada Tikus jantan Putih, Skripsi, Fakultas Farmasi, Universitas Gadjah Mada, Jogjakarta.

Setiani, L. A., 2010, Efek Infusa Daging Buah Mahkota Dewa (Phaleria macrocrpa (Scheff.) Boerl) terhadap Penurunan Kadar Asam Urat Darah Mencit Putih Jantan yang Diinduksi Potassium Oxonate, Skripsi, Fakultas Farmasi Universitas Muhammadiyah Surakarta, Surakarta.

Simon, H., Etikun, M.J, Godine J.E.,Hellen, D.,Kutter, I.,Shellito, and P.C.,Stern, T.A., 2001, Gout Information Service Inc, New York. (http://www.nelcon rected.com).

Siswanto, A., dan Nunuk Aries Nurulita, 2005, Daya Antiinflamasi Infus Daun Mahkota Dewa (Phaleria macrocarpa (Scheff.) Boerl) pada Tikus Putih (Rattus norvegicus) Jantan, Pharmacon, Fakultas Farmasi, Universitas Muhammadiyah Purwokerto, Jogjakarta.

Siswono, 2001, Mahkota Dewa "Racun" Irian yang Berkhasiat (online), (gizinet.com) diakses 4 Oktober 2001)

Sudewo, B., 2004, Tanaman Obat Populer Penggempur Aneka Penyakit, Agromedia Pustaka, Jakarta.

Winarto, W.P., dan Tim Karyasari, 2003, Memanfaatkan Bumbu Dapur untuk Mengatasi Aneka Penyakit, Agromedia Pustaka, Jakarta.

Zhao, X., Zhu, X., and Pan, Y., 2005, Effects Of Cassia Oil On Serum and Hepatic Uric Acid Levels In Oxonate-Induced Mice and Xantine Dehiydrogenase and Xantin Oksidase Aktivities In Mouse Liver, Journal Of Ethnopharmacology. 